\title{
血管内皮機能検査自動化システム実現のためのプローブ位置補正アルゴリズムの開発
}

\section{Development of US Probe Position Adjusting Algorithm for \%FMD Auto Measurement System}

\section{O池田優 ${ }^{1}$, 山口喬弘 ${ }^{2.3}$, 小林英津子 ${ }^{2}$, 佐久間一郎 ${ }^{2}$, 神保泰彦 ${ }^{4}$, 山下優子 ${ }^{5}$, 望月剛 ${ }^{5}$, 伊藤貴司 ${ }^{5}$, 宮田哲郎 ${ }^{6}$, 吉栖正生 ${ }^{7}$}

1. 東京大学工学部, 2. 東京大学大学院工学系研究科, 3. 日本学術振興会特別研究員,

4. 東京大学大学院新領域創成科学研究科, 5. アロ力株式会社研究所,

6. 東京大学大学院医学系研究科, 7. 広島大学大学院医歯薬学総合研究科

OYu Ikeda ${ }^{1}$, Takahiro Yamaguchi ${ }^{2,3}$, Etsuko Kobayashi ${ }^{2}$, Ichiro Sakuma², Yasuhiko Jimbo ${ }^{4}$,

Yuko Yamashita ${ }^{5}$, Takashi Mochizuki ${ }^{5}$, Takashi Itou $^{5}$, Tetsuro Miyata ${ }^{6}$ and Masao Yoshizumi ${ }^{7}$

1. Faculty of Engineering, The University of Tokyo, 2. School of Engineering, The University of Tokyo,

3. JSPS Research Fellow, 4. Graduate School of Frontier Sciences, The University of Tokyo,

5. Research Lab., ALOKA Co. Ltd., 6. Graduate School of Medicine and Faculty of Medicine, University of Tokyo,

7. Graduate School of Biomedical Sciences, Hiroshima University

\section{1. 作最}

現在心臟の冠動脈疾患や脳血管障害のリスクファクターと考え られている血管内皮機能低下の評価法として血管内皮機能検查 法が考案されている.この検査法は, 被験者の下腕部を 5 分間駆 血し, 駆血解除後の上腕動脈の安静時に対する血管径増加率 (\%FMD)を指標としており,以下の式で表される.

$$
\% \mathrm{FMD}=\frac{D_{\max }-D_{p r e}}{D_{p r e}} \times 100
$$

$D_{\max }:$ 最大拡張血管径 $D_{p r e}$ : 安静時血管径

この生理学的現象は，血管内皮細胞が NO 等の内皮依存弛 緩因子を放出することで血管内のシェアストレスを一定に保つ働 きを有することに因り，駆血解除後約 30 秒で最大血管拡張がみ られる. 急激な血流量の増加はシェアストレスの増加につながり, 血管拡張の要因となる. \%FMD は健常者で $10 \%$ 超に対し, 動脈 硬化危険因子度の高い患者では 3\%程度にとどまるといわれてい る. 現在は，医師がプローブ操作及び血管径計測を行っている が, 計測時間が長い, 検查に熟練を要する, 検查結果にばらつき が生じる等の問題点が指摘されている. そこで我々は, 超音波診 断装置, 超音波プローブ保持マニピュレータ, 画像処理及びマニ ピュレータ制御用パソコンからなる, 血管内皮機能検査自動化シ ステムを開発してきた. 本発表では, 超音波プローブ保持マニピ ュレータ及び画像処理ソフトの開発について報告する.

\section{2. 方法}

2.1 怊音波プロープ保持マニピュレータ 血管の動きに対し てプローブ位置を追従させ，超音波画像上で血管を確実に描 出するため, 計 6 自由度を有するプローブ保持マニピュレー タを製作した．本マニピュレータの駆動部は極力低い位置に 配置し，機構の小型軽量化を行い，機構の安定性及び動作速 度の向上を図った.製作したマニピュレータをFig. 1 に示す。

2.2 血管自功追従アルゴリズム 血管自動追従アルゴリズ ムにおいては，血管径の認識率，血管径，血管画像の傾きを 評価基準とし，血管追従動作時には現時点での各值及び 1 制 御周期前の各值を比較し，その変化とモータの動作方向を考 慮してより高速に血管画像に追従できるよう設計した。

\section{3. 枰洒实験}

開発した血管内皮機能検査自動化システムを用い,腕の形を 模擬して作成した円筒形のファントムを用いて血管追徒精度の評 価を, 2 名の被験者に対して\%FMD 計測を行った.

その結果, 血管追従前後において血管径の変化はほとんど見 られず, その差の標準偏差も超音波画像診断装置の分解能
$(0.15 \mathrm{~mm})$ と比較して十分小さかった．また，被験者に対す る\%FMD 計測実験における血管径計測結果の一例を Fig.2 に 示す.

\section{4. 蛣謟}

小型軽量の超音波プローブ保持マニピュレータ，血管とプ ローブの位置関係に応じた高速な血管画像追従の可能な血管 自動追従アルゴリズム等からなる血管内皮機能検查自動化シ ステムを構築し，同システムを用いて血管追徉精度計测実験 及び被験者を対象にした\%FD 計測実験においてその有用性 を検証した。

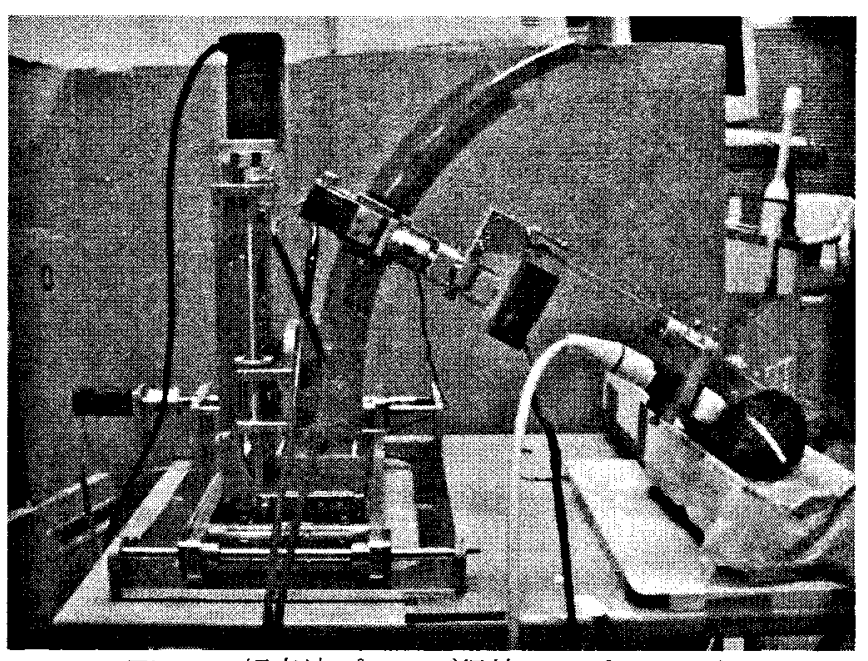

Fig. 1 超音波プロープ保持マニピュレータ

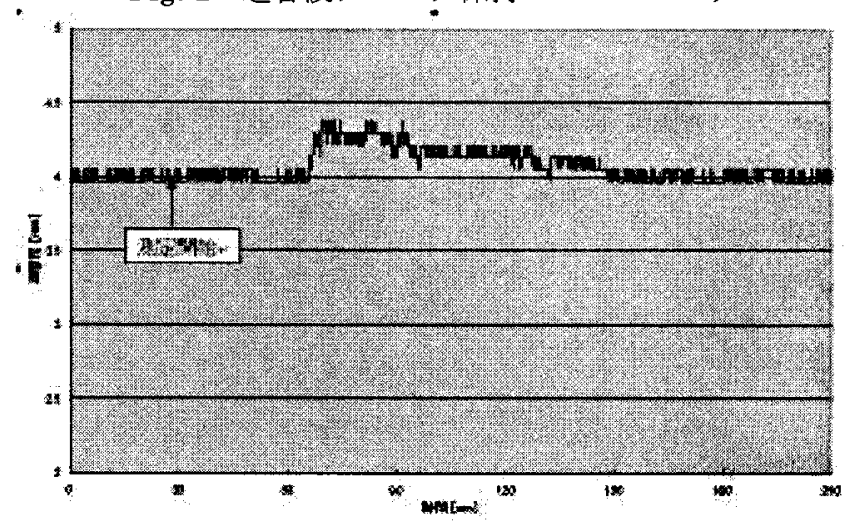

Fig. 2 血管径計測結果の一例 